\title{
Phytotoxic effects of Aeschynomene fluminensis Vell. on the initial growth of weeds
}

\section{and cultivated plants}

\author{
Efeito fitotóxico de Aeschynomene fluminensis Vell. sobre o crescimento inicial de plantas invasoras \\ e cultivadas
}

Efecto fitotóxico Aeschynomene fluminensis Vell. sobre el crecimiento inicial de plantas invasoras y cultivadas

Larissa Éllen Coelho

ORCID: https://orcid.org/0000-0002-9522-2233 State University of Maringá, Brazil

E-mail: Larissa.coelho27@gmail.com

Silvana Maria de Oliveira

ORCID: https://orcid.org/0000-0002-4809-3205 State University of Maringá, Brazil

E-mail: smoliveira@uem.br

Luiz Antonio de Souza

ORCID: https://orcid.org/0000-0003-2180-3980 State University of Maringá, Brazil

E-mail: lasouza@uem.br

Lindamir Hernandez Pastorini

ORCID: https://orcid.org/0000-0003-4679-4718 State University of Maringá, Brazil

E-mail: 1hpastorini@uem.br

\begin{abstract}
Allelopathy is analyzed as an alternative to herbicides due to the inhibitory or beneficent activities of its compounds with other organisms. Current paper discusses the effects of Aeschynomene fluminensis Vell. fractions on cultivated plant species, Lactuca sativa L. and Glycine max (L.) Merril, and on weeds, Ipomoea grandifolia (Dammer) O'Donnel and Digitaria insularis (L.) Fedde. Aqueous fractions at 0.80; 0.40; 0.20 and $0.10 \mathrm{mg} \mathrm{mL}^{-1}$ concentrations were employed for initial growth tests. Seeds were pre-germinated in distilled water and transferred to petri plates with separate fractions at different concentrations. Plates were maintained for $48 \mathrm{~h}$ in a germination chamber at $25^{\circ} \mathrm{C}$ for L. sativa and I. grandifolia and at $30^{\circ} \mathrm{C}$ for G.max and D. insularis. The length of hypocotyl (LH) and root (LR) was measured and LR and foliar length (LF) were taken for $D$. insularis seedlings. Parameters were employed to calculated inhibition percentage. Plants with morphological changes were fixed and analyzed anatomically. Results revealed LH and LR inhibition of lettuce seedlings in fractions with highest concentration rates. The same has been reported in the case of I. grandifolia. Butanolic, methanolic and chloroform fractions did not affect negatively soybean seedlings but they inhibited $D$. insularis seedlings' LR. A. fluminensis fractions, especially at higher concentrations, inhibited seedlings' growth and confirmed their phytotoxic capacity.
\end{abstract}

Keywords: Inhibition; Fractions; Hypocotyls; Root; Soybean.

\section{Resumo}

A alelopatia vem sendo estudada como uma forma alternativa ao uso de herbicidas por seus compostos terem ação inibitória ou benéfica a outros organismos. No trabalho foram analisados os efeitos das frações de Aeschynomene fluminensis Vell. sobre espécies cultivadas, Lactuca sativa L. e Glycine max (L.) Merril, e espécies invasoras, Ipomoea grandifolia (Dammer) O'Donnel e Digitaria insularis (L.) Fedde. As frações aquosas nas concentrações de 0,$80 ; 0,40 ; 0,20$ e $0,10 \mathrm{mg} \mathrm{mL}^{-1}$ foram utilizadas nos testes de crescimento inicial, realizando-se a pré-germinação das sementes em água destilada, que posteriormente foram transferidas para placas de Petri contendo as frações, separadamente, nas diferentes concentrações. As placas foram mantidas por 48 horas em câmara de germinação a $25^{\circ} \mathrm{C}$ para L. sativa e I. grandifolia e $30^{\circ} \mathrm{C}$ para G. max e D. insularis. Após este período foi obtido o comprimento do hipocótilo $(\mathrm{CH})$ e da raiz $(\mathrm{CR})$ e para plântulas de D. insularis, o CR e o comprimento foliar $(\mathrm{CF})$. Esses parâmetros foram utilizados para o cálculo da porcentagem de inibição e as plantas que apresentaram alterações morfológicas, foram fixadas e analisadas anatomicamente. Os resultados indicaram que ocorreu inibição do $\mathrm{CH}$ e do $\mathrm{CR}$ das plântulas de alface mantidas nas frações de maior concentração, sendo o mesmo observado para I. grandifolia. As frações butanólica, metanólica e clorofórmica não afetaram negativamente as plântulas de soja, no entanto, essas 
mesmas frações inibiram o CR de plântulas de D. insularis. Assim, as frações de A. fluminensis, principalmente de maior concentração, inibiram o crescimento das plântulas, confirmando o seu potencial fitotóxico.

Palavras-chave: Inibição; Frações; Hipocótilo; Raiz; Soja.

\section{Resumen}

La alelopatía es estudiada como una alternativa al uso de los herbicidas por la acción inhibidora o beneficiosa que los compuestos tienen sobre otros organismos. En el trabajo se analizaron los efectos de las fracciones de Aeschynomene fluminensis Vell. sobre especies cultivadas, Lactuca sativa L. y Glycine max (L.) Merril, y especies invasoras, Ipomoea grandifolia (Dammer) O’Donnel y Digitaria insularis (L.) Fedde. En las pruebas iniciales de crecimiento se utilizaron fracciones acuosas con concentraciones de 0,$80 ; 0,40 ; 0,20$ y $0,10 \mathrm{mg} \mathrm{mL}^{-1}$, pre-germinando las semillas en agua destilada, que luego fueron transferidas a placas Petri que contenían las fracciones, por separado, en las diferentes concentraciones. Las placas se mantuvieron durante 48 horas en una cámara de germinación a $25^{\circ} \mathrm{C}$ para L. sativa e I. grandifolia y $30^{\circ} \mathrm{C}$ para G. max y D. insularis. Luego de este período, se obtuvo la longitud del hipocótilo $(\mathrm{CH})$ y raíz $(\mathrm{CR})$ y para plántulas de $D$. insularis, la $\mathrm{CR}$ y la longitud de la hoja $(\mathrm{CF})$. Estos parámetros se utilizaron para calcular el porcentaje de inhibición y las plantas que presentaron cambios morfológicos fueron fijadas y analizadas anatómicamente. Los resultados indicaron que hubo inhibición de CH y CR de plántulas de lechuga mantenidas en las fracciones de mayor concentración, observándose lo mismo para I. grandifolia. Las fracciones butanólica, metanólica y clorofórmica no afectaron negativamente a las plántulas de soja, sin embargo, estas mismas fracciones inhibieron la RC de las plántulas de D. insularis. Así, las fracciones de A. fluminensis, principalmente las de mayor concentración, inhibieron el crecimiento de las plántulas, confirmando su potencial fitotóxico.

Palabras clave: Inhibición; Fracciones; Hipocótilo; Raíz; Soja.

\section{Introduction}

Weeds compete the crop plants by limited available nutrients, space, light, and water (Jabran et al., 2015). Weeds cause damage to the environment due to their invasion of cultivated and natural areas, representing one of the main problems of world agriculture. They cause reduced crop yields and changes in ecological processes in the environment (Ximenez et al., 2019). The excessive use of herbicides might cause soil and water pollution and damage to human health (Imatomi et al., 2015). There are several ways by which weeds are disseminated. They are currently controlled by chemical agents, albeit with high contamination risks for the applier and for the environment. Mechanical or physical control methods may become unviable due to high production costs. Allelopathy has became an important tool to identify plants with potential allelochemicals. Such, interest in the use of allelochemicals, as bio-herbicides, is on the increase for weed management (Gindri et al., 2020; Ximenez et al., 2019).

Aeschynomene fluminensis Vell., belonging to the Fabaceae family, is distributed throughout several states in Brazil, such as Paraná and Mato Grosso do Sul. Phytochemical studies of its leaves and branches, undertaken by Ignoato et al. (2012), isolated flavonoids kaempferitrin, quercitin, avicularin, daidzein, iso-hemifloin, and steroids sitosterol and stigmasterol. The above-mentioned chemical compounds suggested a possible allelopathic potential and their use as bio-herbicides. Flavonoids are a class of distinct compounds produced by plant secondary metabolism that inhibit or promote plant development and have a relationship with auxin transport (Franco et al., 2015). Flavonoids have a wide range of activities in plants' physiology, biochemistry and ecology (Taylor \& Grotewold, 2005), coupled to allelopathic functions (Franco et al., 2015). Yan et al. (2014) reported the inhibitory effect of flavonoids isolated from Stellera chamaejasme L. on the growth of Arabidopsis thaliana L. seedlings.

The Ipomoea grandifolia (Dammer) O’Donnel (morning glory) and the Digitaria insularis (L.) Fedde (sourgrass) are the commonest weeds in plantations. The I. grandifolia is a weed that entwines around plants and may impair soybean plants from early development stages to harvest time (Souza \& Lorenzi, 2005). Another weed that attacks soybean plants is $D$. insularis. This species, during the post-emergence period, has been cited as susceptible and moderately susceptible to glypho sate, in addition to being tolerant to several other herbicides such as 2,4-D (Lorenzi, 2006). Thus, sourgrass is one of the most problematic weeds. It is an aggressive species in the allocation of resources from the environment (Martins et al., 2017) 
Glycine max Merril (soybean) is cultivated in almost all regions worldwide. Great diversity in climate requirements, featuring different and numberless cultivars, makes possible its planting in South and North America. High nutrition rates and diversification of cultivars warrant intense farming worldwide. Brazil is the largest soybean producer in the world (harvest 2019-2020) (Embrapa, 2021).

Current assay evaluates the allelopathic effect of $A$. fluminensis fractions by bio-assays involving initial growth in lettuce (Lactuca sativa L.), soybean (Glycine max Merril), morning glory (Ipomea grandifolia (Dammer) O’Donnel) and sourgrass (Digitaria insularis (L.) Fedde) seedlings and possible morpho-anatomic alterations.

\section{Methodology}

\subsection{Botanical material and organic fractions}

Aeschynomene fluminensis was harvested in March 2008 on the floodplain of the high river Paraná, near Porto Rico, PR, Brazil, bordering on the municipality of Baitaporã, MS, Brazil. A voucher of the vegetal material was deposited in the Herbarium of the Universidade Estadual de Maringá, under registration HUEM 15708. Different organic fractions of A. fluminensis leaves, previously obtained by Ignoato et al. (2012), were kept under refrigeration and ceded for allelopathic evaluation.

\subsection{Solubilization of organic fractions}

The mass of $0.04 \mathrm{~g}$ was weighed to obtain the water extracts of different concentrations of hexane, methanolic, butanolic, hydromethanolic and chloroform fractions. The mass was solubilized and diluted in distilled water to obtain $50 \mathrm{~mL}$ $(\mathrm{m} / \mathrm{v})$ from which a $25 \mathrm{~mL}$ aliquot was retrieved. The remaining part was diluted once more for four times to obtain four concentrations: $0.8 ; 0.4 ; 0.2 ; 0.1 \mathrm{mg} \mathrm{mL}^{-1}$. The same process, doubling mass and water, was repeated for the bio-assays on soybean growth to obtain double the fraction volume, maintaining $0.8 \mathrm{mg} \mathrm{mL}^{-1} ; 0.4 \mathrm{mg} \mathrm{mL}^{-1} ; 0.2 \mathrm{mg} \mathrm{mL}^{-1} ; 0.1 \mathrm{mg} \mathrm{mL}^{-1}$ concentrations.

\subsection{Bioassays on initial growth}

Cypselae of L. sativa and G. max, I. grandifolia and D. insularis seeds were germinated in distilled water for the initial growth bio-assays. I. grandifolia and D. insularis seeds were obtained from Agro Cosmos Agrícola e Serviços Rurais Ltda. Cypselae of lettuce, GranRapids-TBR, without any agrotoxics, were obtained from the firm Isla Sementes, and soybean seeds, without any treatment, BMX POTENCIA RR, lot MCF 08/14063, were obtained from Cocamar Ltda.

Ipomoea grandifolia seeds required dormancy breaking, with chemical scarification by concentrated sulfuric acid for $40 \mathrm{~min}$, and washing in running water for $5 \mathrm{~min}$.

After germination, lettuce cypselae and seeds of $I$. grandifolia and D. insularis were placed in $9 \mathrm{~cm}$-petri dishes with $5 \mathrm{~mL}$ of distilled water. Further, soybean seeds were distributed between two sheets of Germitest paper, moistened with distilled water, and kept in rolls. Petri plates and rolls were conditioned in a germination chamber at a 12-h photoperiod, within a light regime by 20 White fluorescent lamps and a dark regime, at a constant temperature of $25^{\circ} \mathrm{C}$ for $L$. sativa and $I$. grandifolia and at $30^{\circ} \mathrm{C}$ for G. max and D. insularis. Mean germination times reached $24 \mathrm{~h}$ for L. sativa and I. grandifolia and $48 \mathrm{~h}$ for G. max and D. insularis.

After radicle protrusion ( $2 \mathrm{~mm})$, ten seedlings of L. sativa, I. grandifolia and D. insularis were transferred to $9 \mathrm{~cm}-$ diameter petri plates, with 2 discs of filter paper and $5 \mathrm{~mL}$ of hexane, methanolic, butanolic, hydromethanolic or chloroform fraction, at the correspondent concentration, and covered with a plastic film to prevent evapotranspiration. Further, five G. max 
seedlings were placed between the two filter paper discs, conditioned in $9 \mathrm{~cm}$-diameter petri plates with the fractions, as previously mentioned.

Four replications were done for each treatment, totaling 500 G. max seedlings and 100 L. sativa, I. grandifolia and D. insularis seedlings. Plates were kept in germination chambers during $48 \mathrm{~h}$ in the same conditions and temperatures, as in the germination process for each species.

The length of the hypocotyl (LH) and root (LR) was taken for L. sativa, G. max and I. grandifolia. Length of root (LR) and leaf (LF) of $D$. insularis was measured by millimeter paper after $48 \mathrm{~h}$ incubation.

\subsection{Inhibition percentage of initial growth}

Inhibition percentage of initial growth was calculated by rates taken in the bio-assays of initial growth (length of root, hypocotyl and leaf), according to formula:

$$
\% \text { inhibition }=(\mu \mathrm{T}-\mu \mathrm{C}) / \mu \mathrm{C} \times 100
$$

where $\mu \mathrm{T}$ is mean of treatments (length of root, hypocotyl and leaf) and $\mu \mathrm{C}$ is the mean of controls. Results are given in bar graphs; positive results imply stimulation of analyzed parameters and negative ones denote inhibition, according to method by Oliveira et al. (2012), modified.

\subsection{Morphoanatomic evaluation}

Five seedlings of each treatment, obtained from growth bioassays with methanolic, butanolic and hydromethalonic fractions, at $0.8 \mathrm{mg} \mathrm{mL}^{-1}$ concentration, and five seedlings of $I$. grandifolia, treated with methanolic, butanolic, hydromethanolic and chloroform fractions, at $0.8 \mathrm{mg} \mathrm{mL}^{-1}$ concentration were transferred to fixation solution of glutaraldehyde $1 \%$, in phosphate buffer $0.1 \mathrm{M} \mathrm{pH} 7.2$ (Karnovsky, 1965). They underwent dehydration in an alcoholic series after $48 \mathrm{~h}$ (Johansen, 1940). Root fragments of the middle region, between the root apex and the collet were fixed in gluteraldeido, embebbed in historesin and cross sectioned on a rotary microtome according to the standard protocol (Guerrits \& Horobin 1991) and stained in toluidine blue (O’Brien et al., 1964).

Photographs of the sections were taken by light microscope locked to digital camera Leica EZ4D and processed by Leica Application Suite 1.8.

Total root diameter, the diameter of the central cylinder and thickness of radicular parenchyma were measured to detect changes in the seedlings' morphoanatomy. Measurements were made by Image Pro Plus.

\subsection{Statistical analysis}

Experiment was totally randomized. Data that complied with normality and homoscedasticity were analyzed by ANOVA and compared by Tukey's test $(\mathrm{p}<0.05)$. When presuppositions of normality and homogeneity were not complied with, data were analyzed by Kruskal-Wallis non-parametric test and compared by Dunn's post-test $(\mathrm{p}<0.05)$. Statistical programs Action Stat 3.1 and BioEstat 5.4 were employed for analyses.

\section{Results and Discussion}

\subsection{Lactuca sativa seedlings treated with A. fluminensis fractions.}

Analyses of results obtained from bioassays on initial growth showed that lettuce seedlings were significantly inhibited for hypocotyl and root size (Figure 1 A, B), maintained in different fractions. The hexane fraction, which failed to inhibit lettuce seedlings, was the exception. Mean length of hypocotyl and root decreased as concentration increased. Effect 
depended on the dose and the greatest difference occurred in lettuce seedlings maintained in chloroform fraction at $0.8 \mathrm{~g} \mathrm{~mL} \mathrm{~m}^{-1}$ concentration.

Figure 1 - Inhibition of growth of seedlings over action of Aeschynomene fluminensis fractions.
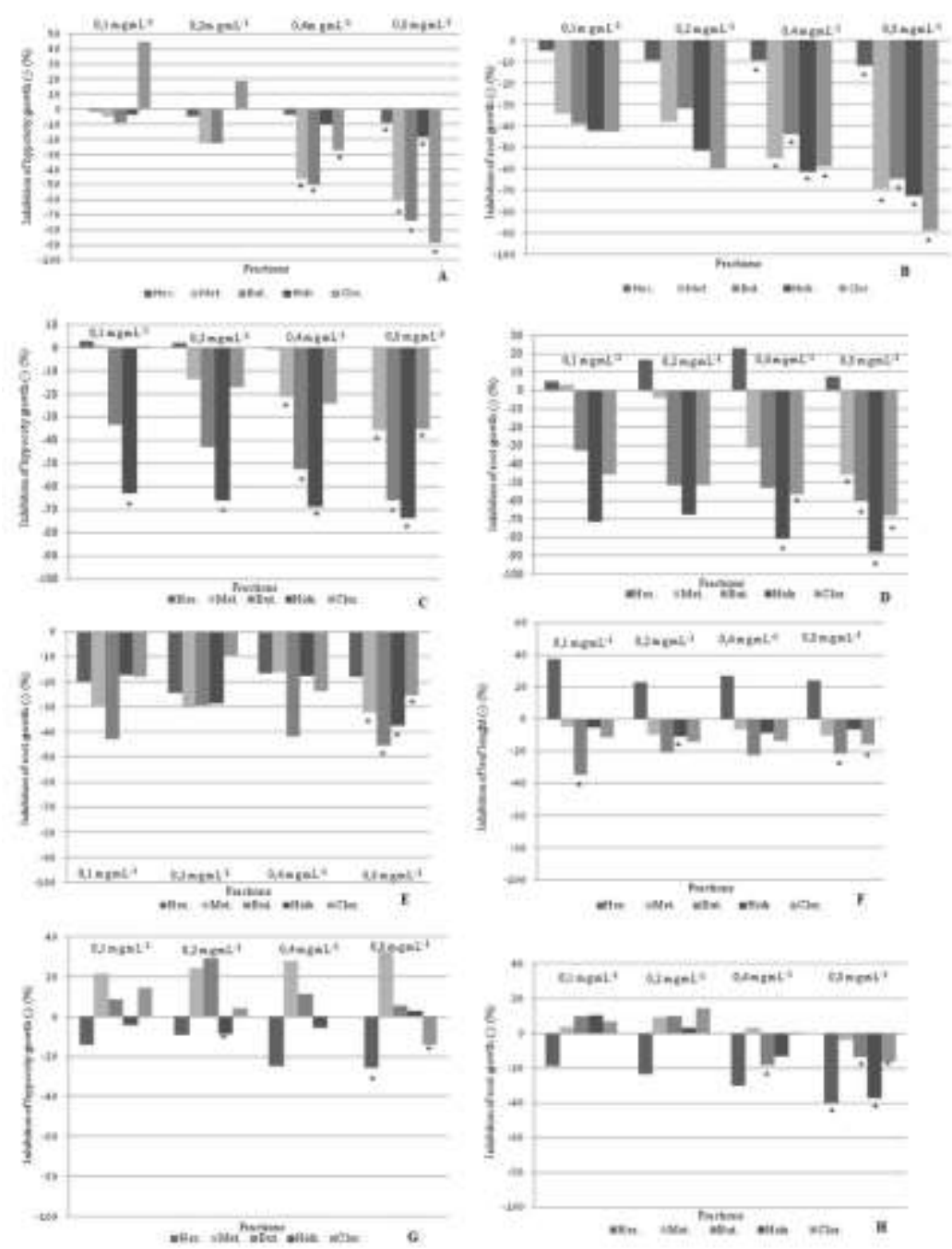

*Hypocoty (A) and root (B) growth of Lactuca sativa; hypocoty (C) and root (D) growth of Ipomea grandifolia; root growth (E) and leaf lenght $(\mathrm{F})$ of Digitaria insularis; hypocoty $(\mathrm{G})$ and root $(\mathrm{H})$ growth of Glycine Max. *Indicates statistically significant differences of the test control through the Kruskal-Wallis test with post-test Dumm $(\mathrm{p}<0,05)$. Source: Authors

Decrease of root length and the characteristic increase of radicular cortex seem to be typical responses of roots treated with allelochemicals, reported by several authors (Pires et al., 2001; Soares et al., 2002; Alliota et al., 2004).

Morphoanatomic data reveal the thickening of the root (Table 1). In all parameters analyzed, root diameter, central diameter and thickness of root parenchyma have significantly higher rates than control. This is especially true for the thickness of the root parenchyma which doubled in the hydromethanolic fraction at $0.8 \mathrm{mg} \mathrm{mL}^{-1}$ concentration, compared to the control. Figure 2 also shows an increase of thickness in root parenchyma in all treatments, with higher rates for the hydromethanolic fraction. 
Table 1- Quantitative anatomy of root sections of Lactuca sativa (L.) seedlings under the action of the methanolic, butanolic and hydrometanolic fractions of Aeschynomene fluminensis.

\begin{tabular}{llllll}
\hline Target specie & Fractions & Concentractions & RD & CD & TRP \\
\hline & Methanolic & Control & $461,03 \mathrm{~b}$ & $109,59 \mathrm{~b}$ & $135,92 \mathrm{~b}$ \\
& & $0,8 \mathrm{mg} \mathrm{mL}^{-1}$ & $810,11 \mathrm{a}$ & $180,83 \mathrm{a}$ & $269,6 \mathrm{a}$ \\
Lactuca sativa & Butanolic & Control & $461,03 \mathrm{~b}$ & $109,59 \mathrm{~b}$ & $135,92 \mathrm{~b}$ \\
& & $0,8 \mathrm{mg} \mathrm{mL}^{-1}$ & $649,06 \mathrm{a}$ & $184,92 \mathrm{a}$ & $209,97 \mathrm{a}$ \\
& \multirow{3}{*}{ Hydrometanolic } & Control & $461,03 \mathrm{~b}$ & $109,59 \mathrm{~b}$ & $135,92 \mathrm{~b}$ \\
& & $0,8 \mathrm{mg} \mathrm{mL}^{-1}$ & $1044,73 \mathrm{a}$ & $270,34 \mathrm{a}$ & $332,15 \mathrm{a}$
\end{tabular}

RD- root diameter; CD- central diameter; TRP- thickness of the root parenchyma. Unit of measure $\mu \mathrm{m}$ (micrometers). * Means with equal lowercase letters in the column do not present statistical differences between them, using the ANOVA tests compared by Tukey $(\mathrm{p}<0.05)$ and Kruskal-Wallis compared to the Dumm pos-test $(\mathrm{p}<0,05)$.

Source: Authors

Figure 2. Cross sections of Lactuca sativa roots under the action of Aeschynomene fluminensis fractions.

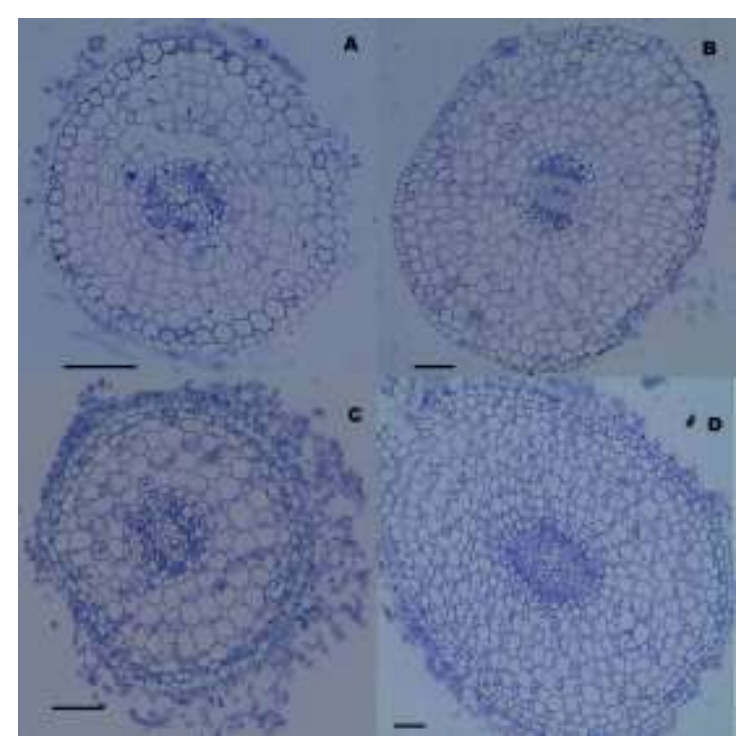

A-Control, B-Methanolic $0.8 \mathrm{mg} \mathrm{mL}$-1, C-Butanolic $0.8 \mathrm{mg} \mathrm{mL}$-1, D-Hydromethanolic $0.8 \mathrm{mg} \mathrm{mL}$-1. (Scale: $100 \mu \mathrm{m})$ Source: Authors

Root thickening was also registered by Barreiro et al. (2005), in which the pure Stryphnodendron adstringens (Mart.) Coville ("barbatimão") extract reduced root formation with great intensity, even causing necrosis.

Lettuce plants in all fractions at $0.8 \mathrm{mg} \mathrm{mL}^{-1}$ concentration had greater growth inhibition (Figure 1). Excepting the hexane fraction, the above also occurred in seedlings at $0.4 \mathrm{mg} \mathrm{mL}^{-1}$ concentration. The chloroform fraction had the highest inhibition rate among the fractions that inhibited lettuce seedlings' roots, with almost $90 \%$, followed by the hydromethanolic fraction with $70 \%$.

Increase in root diameter and hypocotyl hypertrophy in several plants is associated with the formation of endogenous formation of ethylene due to stress (Lorteau et al., 2001; Zhang et al., 2003). Moreover, Peres et al. (2004) suggest that this is a greatly important ecological aspect. The plant's competition pressure is reduced due to the inhibition of the development of the root system, favoring neighboring species which may establish a dominance stance. 


\subsection{Ipomoea grandifolia seedlings treated with A. fluminensis fractions.}

The growth of hypocotyl and root of I. grandifolia seedlings was also inhibited, similar to lettuce seedlings (Fig.1 C, D). Silva et al. (2016) reported that all concentrations of leaves and roots of Asemeia extraaxillaris (Chodat) J.F.B. Pastore \& J.R. Abbott inhibited root growth of I. grandifolia. There was a 56\% reduction in hypocotyl growth, plus thickening of root at higher concentration rates.

A significant alteration in hypocotyls size at all concentration occurred in hydromethanolic fractions (Fig. 1C). With the exception of the hexane fraction, A. fluminensis fractions had an inhibiting capacity on I. grandifolia seedlings at concentration $0.8 \mathrm{mg} \mathrm{mL}^{-1}$ with regard to hypocotyl and root length, with inhibition rates over $70 \%$ for hypocotyl length. Hydromethanolic fraction had a higher than $80 \%$ inhibition on root length, at concentration $0.8 \mathrm{mg} \mathrm{mL}^{-1}$, with inhibition increase as concentration increased (Figure 1D). Lima et al. (2009) detected an almost 50\% decrease in the root length of $I$. grandifolia seedlings maintained in Cymbopogon citratus extract at the highest concentration rate, compared to control.

Morphoanatomic parameters revealed thickening of the root, similar to lettuce seedlings (Table 2), in which butanolic, hydromethanolic and chloroform fractions increased root diameter, while the central diameter doubled in the hydromethanolic fractions. Seedlings in methanolic fractions failed to present any significant alteration in the root diameter, except in the thickness of the root parenchyma (Table 2).

Table 2- Quantitative anatomy of root sections of Ipomea grandifolia seedlings treated with methanolic, butanolic, hydrometanolic and chloroform of Aeschynomene fluminensis fractions.

\begin{tabular}{lllll}
\hline Fractions & Concentractions & RD & CD & TRP \\
\hline Methanolic & Control & $555,62 \mathrm{a}^{*}$ & $172,38 \mathrm{a}$ & $172,01 \mathrm{~b}$ \\
\multirow{3}{*}{ Butanolic } & $0,8 \mathrm{mg} \mathrm{mL}^{-1}$ & $776,75 \mathrm{a}$ & $242,11 \mathrm{a}$ & $224,61 \mathrm{a}$ \\
\cline { 2 - 5 } & Control & $555,62 \mathrm{~b}$ & $172,38 \mathrm{~b}$ & $172,01 \mathrm{~b}$ \\
\multirow{3}{*}{ Hydrometanolic } & $0,8 \mathrm{mg} \mathrm{mL}^{-1}$ & $896,45 \mathrm{a}$ & $264,04 \mathrm{a}$ & $243,35 \mathrm{a}$ \\
\cline { 2 - 5 } & Control & $555,62 \mathrm{~b}$ & $172,38 \mathrm{~b}$ & $172,01 \mathrm{a}$ \\
\multirow{3}{*}{ Chloroform } & $0,8 \mathrm{mg} \mathrm{mL}^{-1}$ & $983,28 \mathrm{a}$ & $430,96 \mathrm{a}$ & $262,64 \mathrm{a}$ \\
\cline { 2 - 5 } & Control & $555,62 \mathrm{~b}$ & $172,38 \mathrm{~b}$ & $172,01 \mathrm{~b}$ \\
& $0,8 \mathrm{mg} \mathrm{mL}^{-1}$ & $782,85 \mathrm{a}$ & $251,06 \mathrm{a}$ & $228,45 \mathrm{a}$ \\
\hline
\end{tabular}

RD- root diameter; CD- central diameter; TRP- thickness of the root parenchyma. Unit of measure $\mu \mathrm{m}$ (micrometers). * Means with equal lowercase letters in the column do not present statistical differences between them, using the ANOVA tests compared by Tukey ( $\mathrm{p}<0.05$ ) and Kruskal-Wallis compared to the Dumm pos-test $(\mathrm{p}<0,05)$.

Source: Authors

The control and treatment seedlings consist of diarch primary roots (Figure 3), except the seedling that received treatment with hydromethanolic fraction, which shows root/shoot transition structure (Figure 3-D), probably due to the reduction in size that the root underwent (Figure 4). 
Research, Society and Development, v. 10, n. 2, e37110212551, 2021

(CC BY 4.0) | ISSN 2525-3409 | DOI: http://dx.doi.org/10.33448/rsd-v10i2.12551

Figure 3. Cross sections of Ipomoea grandifolia roots under the action of Aeschynomene fluminensis fractions.

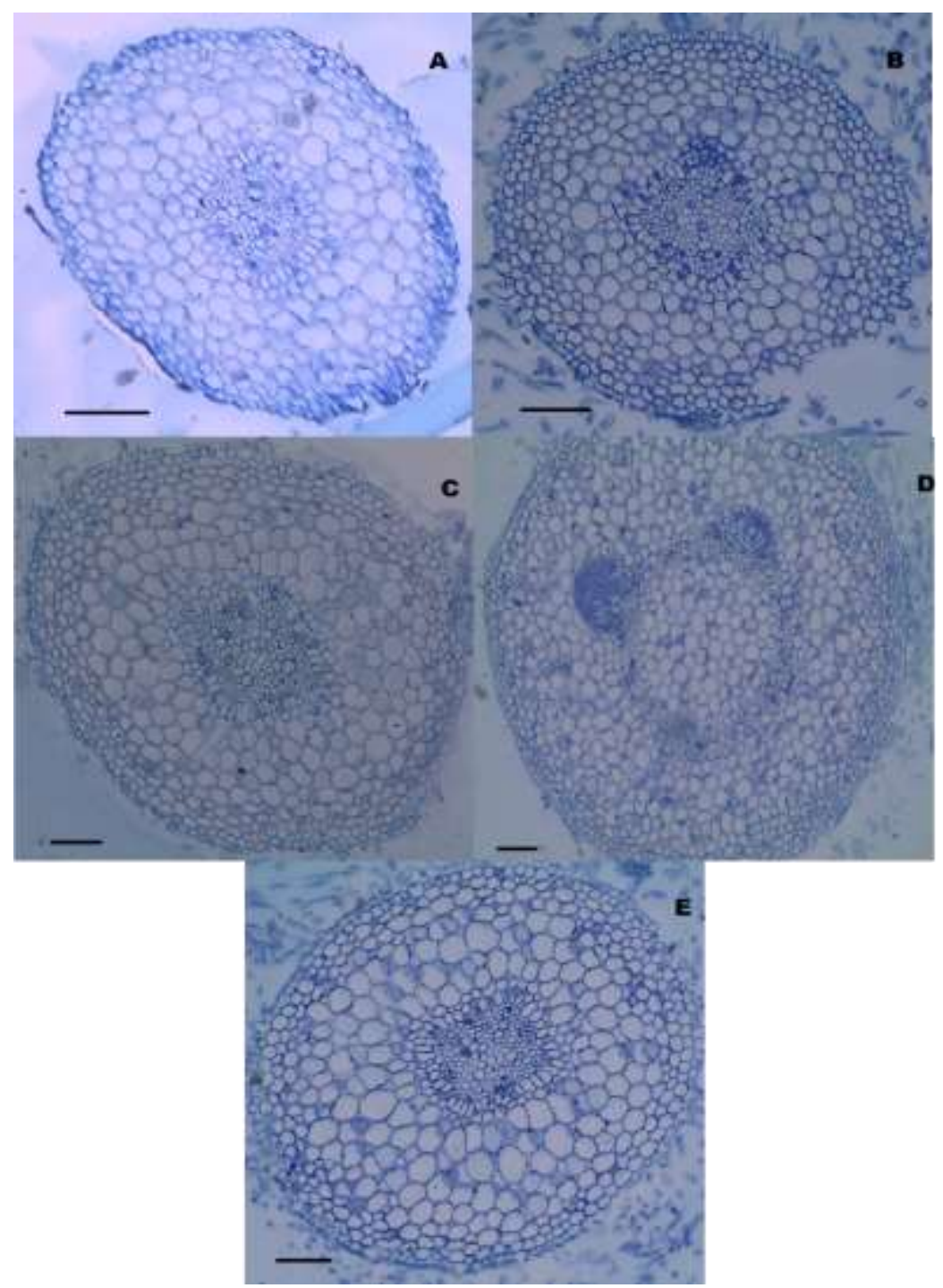

A-Control, B-Metanolic $0.8 \mathrm{mg} \mathrm{mL}$-1, C-Butanolic $0.8 \mathrm{mg} \mathrm{mL} \mathrm{-1,} \mathrm{D-Hydromethanolic} 0.8 \mathrm{mg} \mathrm{mL}$-1. (Scale: $100 \mu \mathrm{m})$ Source: Authors 
Figura 4. Initial growth de Ipomea grandifolia treated with Aeschynomene fluminensis fractions.

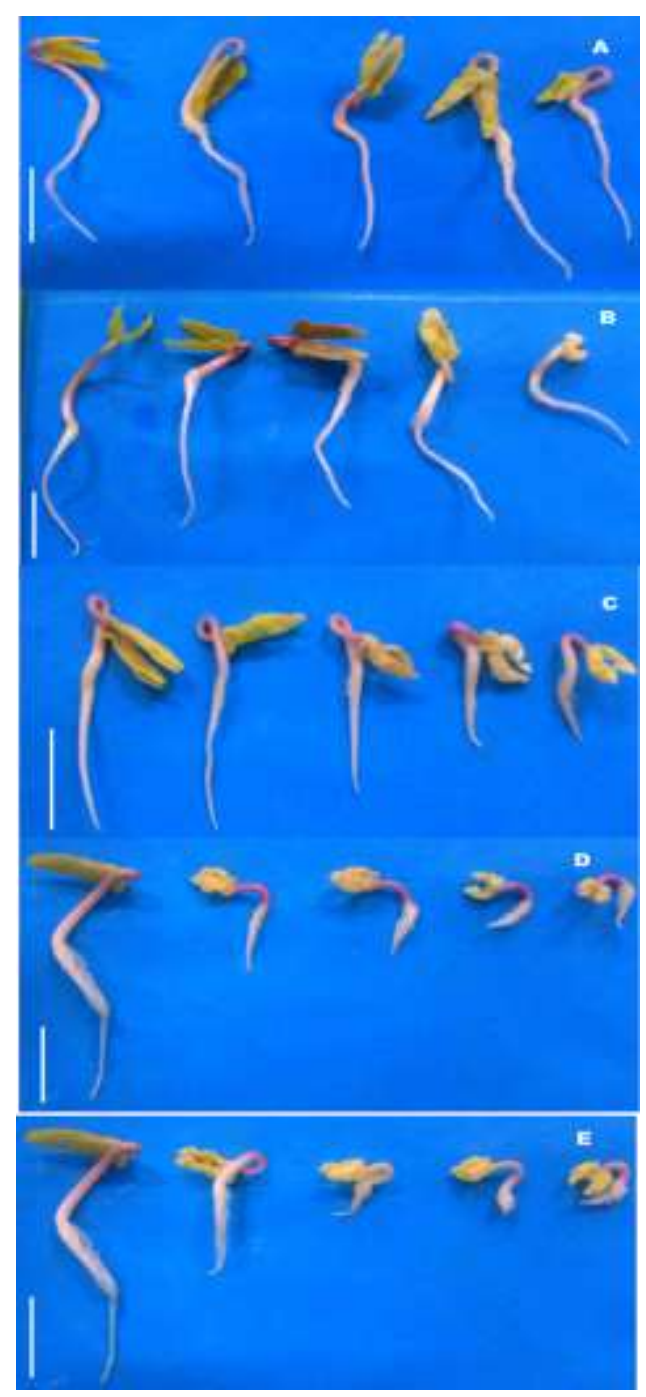

A-Hexane fraction; B- Methanol fraction; C- Butanolic fraction; D- Hydrometanolic fraction; E- Chloroform fraction (Scale: 1cm; Respectively: control; $0,1 \mathrm{mg} \mathrm{mL}^{-1} ; 0,2 \mathrm{mg} \mathrm{mL}^{-1} ; 0,4 \mathrm{mg} \mathrm{mL}^{-1} ; 0,8 \mathrm{mg} \mathrm{mL}^{-1}$ )

Source: Authors

\subsection{Digitaria insularis seedlings treated with $A$. fluminensis fractions.}

D. insularis seedlings were inhibited by A. fluminensis methanolic, butanolic, hydromethanolic and chloroform fractions, at concentration $0.8 \mathrm{mg} \mathrm{mL}^{-1}$, inhibited root growth (Figure 1E), whereas the leaf's highest inhibition rate occurred in seedlings treated with butanolic fraction at $0.1 \mathrm{mg} \mathrm{mL}^{-1}$ concentration, in hydromethanolic fraction at $0.2 \mathrm{mg} \mathrm{mL}^{-1}$ concentration and in methanolic and chloroform fractions at highest concentration (Figure 1F). Sousa et al (2011) reported that D. insularis seedlings were sensitive to castor bean, nim and eucalyptus extracts, especially the latter two, with greater efficaciousness than other extracts.

Although hexanic fraction did not affect seedling growth. However was reported with regard to methanolic fraction, with root lenght significantly less at $0.1 \mathrm{~g} \mathrm{~mL}^{-1}$ concentration, compared to the control.

\subsection{Glycine max seedlings treated with $A$. fluminensis fractions.}

Data related to inhibition percentage showed significant difference, or rather, a significant inhibition of hypocotyl of soybean seedlings in the hydromethanolic fraction at $0.2 \mathrm{mg} \mathrm{mL}^{-1}$ concentration and hexane fraction at $0.8 \mathrm{mg} \mathrm{mL}^{-1}$ 
concentration (Figure 1G). Faria et al. (2009) reported that Stizolobium aterrimum extract had negative effects on root length and soybean hypocotyl. Increase in extract concentration featured the most significant effect.

In the case of root length, there was a greater inhibition in root growth of soybean seedlings in butanolic fraction at $0.4 \mathrm{mg} \mathrm{mL}^{-1}$ concentration and in all fractions at $0.8 \mathrm{mg} \mathrm{mL}^{-1}$ concentration (Figure $1 \mathrm{H}$ ). Seedlings maintained in methanolic fractions for hypocotyl and root growth had positive rates. However, there were no significant morphological changes in the soybean seedlings treated with different fractions (Figure 5)

Figura 5. Initial growth of Glycine max (soybean) treated with Aeschynomene fluminensis fractions.

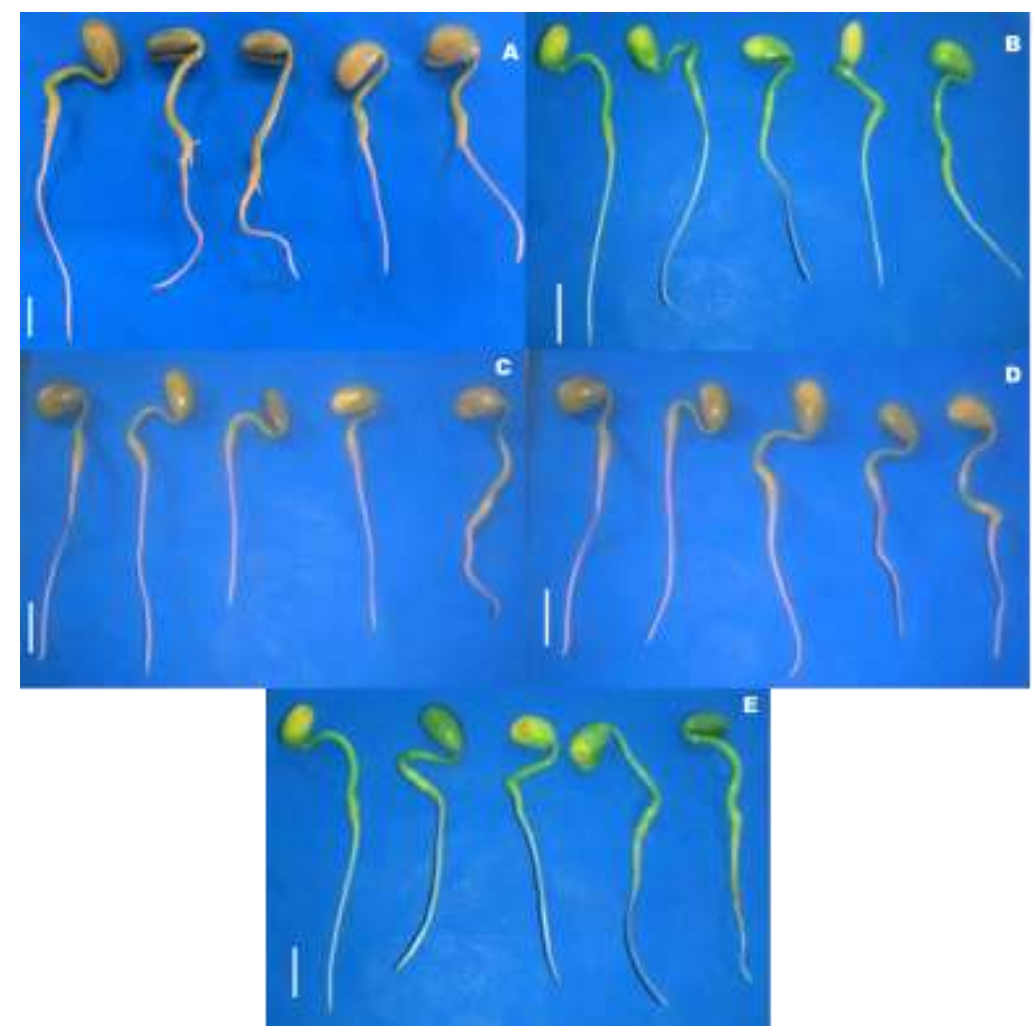

A- Hexane fraction; B- Methanolic fraction; C- Butanolic fraction; D- Hydrometanolic fraction; E- Chloroform fraction (Scale: 1cm; Respectively: control; $0,1 \mathrm{mg} \mathrm{mL}^{-1} ; 0,2 \mathrm{mg} \mathrm{mL}^{-1} ; 0,4 \mathrm{mg} \mathrm{mL}^{-1} ; 0,8 \mathrm{mg} \mathrm{mL}^{-1}$ )

Source: Authors

Although methanolic, butanolic, hydromethanolic and chloroform fractions at $0.8 \mathrm{mg} \mathrm{mL}^{-1}$ concentration significantly inhibited I. grandifolia, exhibiting less 50\%, 60\%, more $80 \%$ and $70 \%$ inhibition, respectively. While G. max seedlings, usually infested by this weed, were only slightly inhibited (Figures 1 ). Which can also be verified by the morphological characteristics of these plants (Figure 4), with evident reduction of the growth of the seedlings of I grandifolia. D. insularis seedlings were similarly affected. The treatments showed more than $30 \%$ inhibition for LR, especially in the hydromethanolic and butanolic fractions at the highest concentration. The butanolic fractions inhibited less than $15 \%$ in soybean seedlings, with no negative effect on the growth of hypocotyls.

Studies on A. fluminensis demonstrated flavonoids, such as kaempferitrin, $\alpha$-raminoisorobin, quercetin, avicularin, the isoflavonoid daidzein, the flavone iso-hemifloin and the dimer epicatechin, procyanidin A2, with anti-inflammatory activities (Ignoato et al., 2012). The above chemical compounds may indicate a possible phytotoxic effect of the plant's fractions. Formagio et al. (2014) revealed a performance inhibition of lettuce cypselae in Copaifera leaf extracts and Acacia podalyriaefolia A. Cunn. flower extracts. The effect is characterized by phenolic and flavonoid compounds. 
Plant flavonoids have relevant functions in the transport of auxins, development of roots and aerial parts, modulation of oxygen-reacting species and signalization in the symbiosis of nitrogen-fixing legumes and bacteria (Weston \& Mathesisu, 2013). According to these authors, flavonoids, largely depending on the structure, may impact the breaking of auxins by IAA oxidase and peroxidase and influence auxin's polar transport. This fact may inhabit seedlings growth and root lengthening, even though the precise manner has not yet been elucidated. In the case, root growth and seedlings' hypocotyl may be altered, similar to L. sativa, I. grandifolia, D. insularis and G. max seedlings in A. fluminensis fractions with the highest concentration rates. Flavonoids, such as quercetin, obtained from Copaifera langsdorffii Desf. leaves inhibited more than $20 \%$ of root growth of sorghum seedlings (Franco et al., 2015).

According to Levizou et al. (2004), flavonoid activities may be highly dependent on concentration rates. Some of these compounds may have an inhibitory or stimulating activity bonded to availability in soil/water in the rhizosphere. It may be associated with growth stimulation of the seedlings' hypocotyl of lettuces in chloroform fractions at the lowest concentration rates, whereas the highest concentration rate inhibited hypocotyl growth. The above may be said of $D$. insularis seedlings where the hexane fraction enhanced leaf growth but inhibited the growth of the root (Figure 1).

\section{Conclusions}

In the present study, significant results occurred in tests with lettuce, a highly sensitive plant with regard to allelochemicals. In addition, the fractions, in higher concentration, inhibited the growth of D. insularis and I. grandifolia, infesting weed of soybean crops.

Thus, organic fractions of A. fluminensis leaves showed phytotoxic effect on weeds.

\section{Acknowledgments}

This study was financed by the Coordenação de Aperfeiçoamento de Pessoal de Nivel Superior (CAPES).

\section{References}

Barreiro, A. P., Delachiave, M. E. A., \& Souza, F. S. (2005). Efeito alelopático de extratos de parte aérea de barbatimão [Stryphnodendron adstringens (Mart.) Coville] na germinação e desenvolvimento da plântula de pepino. Revista Brasileira de Plantas Medicinais, 8(1), 4-8.

EMBRAPA. (2021). Embrapa soja: soja em números (SAFRA 2019/20). https://www.embrapa.br/soja/cultivos/soja1/dados-economicos.

Faria, T. M., Júnior, F. G. G., Sá, M. E., \& Cassiolato, A. M. R. (2009). Efeitos alelopáticos de extratos vegetais na germinação, colonização micorrízica e crescimento inicial de milho, soja e feijão. Revista Brasileira de Ciência do Solo, 33(6), 1625-1633.

Formagio, A. S. M., Masetto, T. E., Vieira, M. C., Zárate, N. A. H., De Matos, A. I. N., \& Volobuff, C. R. F. (2014). Potencial alelopático e antioxidante de extratos vegetais. Bioscience Journal, 30(supplement 2), 629-638.

Franco, D. M., Silva, E. M., Saldanha, L. L., Adachi, S. A., Schley, T. R., Rodrigues, T. M., Dokkedal, A. L., Nogueira, F. T. S., \& Almeida, L. F. R. (2015). Flavonoids modify root growth and modulate expression of SHORT-ROOT and HD-ZIP III. Journal of Plant Physiology, 188, 89-95. https://doi.org/10.1016/j.jplph.2015.09.009

Guerrits, P. O., \& Horobin, R. W. (1991). The application of glycol methacrylate in histotechnology: some fundamental principles. Groningen, Netherlands: University Groningen.

Gindri, D. M., Coelho, C. M. M., Uarrota, V. G., \& Rebelo, A. M. (2020). Herbicidal bioactivity of natural compounds from Lantana camara on the germination and seedling growth of Bidens pilosa. Pesquisa Agropecuária Tropical, 50, e57746. https://doi. 10.1590/1983-40632020v5057746

Ignoato, M. C., Fabrao, R. M., Schuquel, I. T. A., Botelho, M. F. P., Santin, S. M. O., Arruda, L. L. M., Bersani-Amado, C. A., \& Souza, M. C. (2012). Estudo fitoquímico e avaliação da atividade anti-inflamatória de Aeschynomene fluminensis vell. (Fabaceae). Química Nova, 35 (11), 2241-2244.

Imatomi, M., Novaes, P., Miranda, M. A. F. M., \& Gualtieri, S. C. J. (2015). Phytotoxic effects of aqueous leaf extracts of four Myrtaceae species on three weeds. Acta Scientiarum. Agronomy, 37(2), 241-248. https://doi. 10.4025/actasciagron.v37i2.19079

Jabran, K., Mahajan, G., Sardana, V., \& Chauhan, S. B. (2015). Allelopathy for weed control in agricultural systems. Crop Protection, 72, 57e65. http://dx.doi.org/10.1016/j.cropro.2015.03.004 
Johansen, D. A. (1940). Plant michotechnique. McGraw-hill Book Company Inc.

Karnovsky, M. J. (1965). A formaldehyde-glutaraldehyde fixative of high osmolality for use in electron microscopy. Journal of Cell Biology, 27,137-138.

Levizou, E., Karageorgou, P. K., Petropoulou, G., Grammatikopoulos, G., \& Manetas, Y. (2004). Induction of ageotropic response in lettuce radical growth by epicuticular flavonoid aglycones of Dittrichia viscosa. Biologia Plantarum, 48,305-307.

Lima, G. P., Fortes, A. M. T., Mauli, M. M., Rosa, D. M., \& Marques, D. S. (2009). Alelopatia de capim-limão (Cymbopogon citratus) e sabugueiro (Sambucus australis) na germinação e desenvolvimento inicial de corda-de-viola (Ipomoea grandifolia). Publicatio UEPG. Ciências Exatas e da Terra, 15 (2), $121-127$.

Lorteau, M. A., Ferguson, B. J., \& Guinel, F. C. (2001). Effects of cytokinin on ethylene production and nodulation in pea (Pisum sativum) cv. Sparkle. Physiologia plantarum, 112, 421-428.

Lorenzi, H. (2006). Manual de identificação e controle de plantas daninhas: plantio direto e convencional. Nova Odessa, Instituto Plantarum.

O'Brien, T. P., Feder, N., \& Mccully, M. E. (1964). Polychromatic staining of plant cell walls by toluidine blue. Protoplasma, $2,368-373$.

Oliveira, S. C. C., Gualtieri, S. C. J., Domínguez, F. A. M., Molinillo, J. M. G., \& Montoya, R. V. (2012). Estudo fitoquímico de folhas de Solanum lycocarpum A. St.-Hil (Solanaceae) e sua aplicação na alelopatia. Acta Botanica Brasilica, 26 (3), 607-18. https://doi.org/10.1590/S010233062012000300010

Peres, M. T. L. P., Silva, L. B. S., Faccenda, O., \& Hess, S. C. (2004). Potencial alelopático de espécies de Pteridaceae (Pteridophyta). Acta Botanica Brasilica, 18(4), 723-730.

Pires, N. M., Souza, I. R. P., Prates, H. T., Faria, T. C. L., Filho, I. A. P., \& Magalhães, P. C. (2001). Efeito do extrato aquoso de leucina sobre o desenvolvimento, índice mitótico e atividade da peroxidase em plântulas de milho. Revista Brasileira de Fisiologia Vegetal, $13(1)$, 55-65.

Silva, C. B., Oliveira, M., Dias, J. F., Zanin, S. M. W., Santos, G. O., Cândido, A. C. S., Peres, M. T. L. P., Simionatto, E., Miguel, O. G., \& Miguel, M. D. (2016). Atividade alelopática dos lixiviados de Asemeia extraaxillaris (Polygalaceae) sobre o crescimento de Ipomoea cordifolia. Revista Brasileira de Plantas Medicinais, 18(1), 215-222. https://doi.org/10.1590/1983-084X/14_093

Soares, G. L. G., Scalon, V. R., Pereira, T. O., \& Vieira, D. A. (2002). Potencial alelopático do extrato aquoso de folhas de algumas leguminosas arbóreas brasileiras. Revista Floresta e ambiente, 9(1), 199-226.

Sousa, S. F. G., Riquetti, N. B., Tavares, L. A. F., Marasca, I., \& Junior, R. A. (2011). Efeito da utilização de extratos vegetais sobre a germinação de três espécies de plantas espontâneas. Revista Científica Eletrônica de Agronomia, 18(1), 29-33.

Souza, V. C., \& Lorenzi, H. (2005). Botânica Sistemática: Guia Ilustrado para Identificação das Famílias de Angiospermas da Flora Brasileira, Baseado em $A P G$ II. Nova Odessa, Instituto Plantarum de Estudos da Flora Ltda.

Taylor, L. P., \& Grotewold, E. (2005). Flavonoids as developmental regulators. Current Opinon Plant Biology, 8 (3), 317-23. https://doi.org/10.1016/j.pbi.2005.03.005.

Ximenez, G. R., Santin, S. M. O., Ignoato, M. C., Souza, L. A., \& Pastorini, L. H. (2019). Phytotoxic potential of the crude extract and leaf fractions of Machaerium hirtum on the initial growth of Euphorbia heterophylla and Ipomoea grandifolia. Planta Daninha, 37 , e019180433. https://doi.org/10.1590/s0100-83582019370100015

Yan, Z. Q., Guo, H. R., Yang, J. Y., Liu, Q., Jin, H., Xu, R., Cui, H. Y., \& Qin, B. (2014). Phytotoxic flavonoids from roots of Stellera chamaejasme L. (Thymelaeaceae). Phytochemistry, 106, 61-68. https://doi.org/10.1016/j.phytochem.2014.07.013

Weston, L. A., \& Mathesius, U. (2013). Flavonoids: Their structure, biosynthesis and role in the rizosphere, including allelopathy. Journal of Chemical Ecology, 39, 283-297. https://doi.org/10.1007/s10886-013-0248-5

Zhang, Y-J., Lynch, J. P., \& Bown, K. M. (2003). Ethylene and phosphorus availability have interacting yet distinct effects on root hair development. Journal Experimental Botany, 54 (391), 2351-2361. https://doi.org/10.1093/jxb/erg250 